\title{
Review of the Water Footprint Project within Geographically Delineated Area
}

\author{
Stella Symeonidou and Dimitra Vagiona \\ Department of Spatial Planning and Development, Faculty of Engineering, Aristotle University of Thessaloniki, Thessaloniki 54124, \\ Greece
}

\begin{abstract}
During the last decade, there has been an intensive research activity concerning the concept of the Water Footprint (WF) approach, which was firstly introduced by Arjen Hoekstra in 2002. WF is an indicator of direct and indirect freshwater use of a consumer or producer that takes into account water consumption in every step (intermediate and final) along the production chain and services. The concept can be implemented in various levels such as products, consumers, producers, nations and river basins etc.. The water footprint within a geographically delineated area equals the sum of the process water footprints of all processes taking place in the area. The aim of current research is a review of the most important WF studies, with a special focus on applications within regional, basin and administrative unit level. National and global scales are not included in the current paper. The article presents the most widespread methodologies and approaches that attempt to evaluate water footprints of specific defined areas and highlights their recent advances as well as shortcomings in the constantly evolving research efforts.
\end{abstract}

Key words: Water footprint, review, water resources management, geographically delineated area.

\section{Introduction}

The Water Footprint (WF) is an indicator closely correlated with virtual water [1] that was introduced in an effort to relate fresh water use to human consumption. The difference between virtual water and WF is that the latter contains further information such as the type of water used (blue, green or grey) but also when and where it is used. The water footprint of an individual, community or business is defined as the total volume of freshwater used to produce the goods and services consumed by the individual or community or produced by the business [2]. The WF of business is mainly useful to the private sector (hotspots in supply chains and benchmarking of products etc.), while the WF of a given region provide stakeholders with helpful information. This paper discusses the WF within a geographically delineated area which is defined as the total freshwater consumption and pollution within the boundaries of

Corresponding author: Stella Symeonidou, Ph.D. candidate, main research field: water resource management. the area. The area can be a hydrological unit such as a catchment area or a river basin or an administrative unit like a municipality, province, state or nation [2]. This review summarizes research projects applicable at basin level or subnational administrative units and regions. National and global scales are not included in the current review because it is beyond the scope of this topic.

\section{Materials}

This paper analyses three WF methodologies: a stand-alone method according to international Water Footprint Network (WFN) [2] which is the most widespread so far, Life Cycle Assessment (LCA) based methods and Environmentally Extended Input-Output (EEIO) tables and models. The first one provides volumetric WF on the aspect of water resources management, the second one is an impact oriented approach and the third one evaluates the relationship between economic activities and downstream environmental impacts.

According to WFN method, WF can be separated 
into the three components of blue, green and grey water. Blue WF refers to the consumption of surface and groundwater water resources, green WF has to do with rainwater as it does not become run-off and grey $\mathrm{WF}$ is the volume of freshwater that is required to assimilate the load of pollutants given natural background concentrations and existing ambient water quality standards. The four phases of the method are: setting goals and scope, WF accounting, WF sustainability assessment and WF response formulation. Recently, Arjen Hoekstra proposed three pillars under wise freshwater allocation: WF caps per river basin, benchmarks per product and fair shares per community [3].

A WF of a geographically delineated area can be assessed with the top-down or the bottom-up approach. The bottom-up approach computes WF by multiplying all goods and services consumed by the inhabitants of a country, with the corresponding water needs of those goods and services. On the other hand, in the top-down approach, WF is calculated as the total use of water resources in the country by adding to this the imported virtual water and subtracting the exported virtual water. The top-down approach is considered more convenient for quick calculation of nation WF, while the upward approach is more appropriate to calculate the WF of an individual, a company or a smaller geographical area where there are no available input-output data [2]. The bottom-up approach depends on the quality of consumption data, while the top-down approach relies on the quality of trade data. When the different databases are not consistent with one another, the results of both approaches will differ [4].

Over the past decades, one of the most frequent applications of input-output analysis has been the interaction of the economy and the environment [5]. Input-output analysis is a top-down economic technique, which uses sectoral monetary transactions data to account for the complex interdependencies of industries in modern economies [6]. The IO approach to economic data was developed by Nobel prize winner Wassily Leontief [7-9], who also gave an introduction to the input-output method and its application to environmental problems. IO tables have been used widely to account for regional WFS and represent the economic interconnections of the transactions of virtual water among the examined economic sectors.

The Multi-Regional Input-Output (MRIO) model is a useful tool for tracing environmental impacts of consumption between sectors within an economic region and multiple regions [10]. Subnational applications of MRIO are more difficult to implement than international applications, because of inconsistent and misaligned data [11]. The ability to "geo-position" environmental pressure, and link it to regional environmental resource and socio-economic conditions, is vital for assessing sustainable scale and impacts for many environmental resources [12]. EIOA approaches are particularly useful when one wants to look at the direct and indirect water requirements of an entire final consumption pattern of a nation, a region, a lifestyle group or a household. Because such a final consumption pattern is comprised of so many different goods and services that bottom-up approaches have problems in providing all the required process-based descriptions of production and water consumption in their supply chains [13].

EEIO provides a simple and rapid method that can be used to evaluate the upstream environmental impacts associated with downstream economic consumption, as well as the embodied environmental impacts in traded goods [14]. EEIO research can contribute to the establishment of environmental, economic and social data inventories which can be used to inform about the monetary water transactions among economic sectors of the area of interest.

Due to the data intensive and bottom-up nature of traditional life cycle assessment, LCA can be excellent for measuring direct inputs, but presents difficulties when accounting for indirect inputs [15]. Hybrid LCA 
and IO-LCA provide top-down approaches to LCA that accounts for both direct and indirect inputs. Hybrid approaches piecing together LCA and top down approaches are being implemented to address multi-scale issues in geographically delineated areas, by combining the advantages of both bottom-up and top-down approaches.

Several papers have been published in an effort to propose various ways to integrate WF into LCA inventories [16-20]. LCA is the investigation and evaluation of the environmental impacts of a given product or service and consists of four phases: goal and scope, life cycle inventory, life cycle impact assessment and interpretation [21]. Bradley Ridoutt and Stephen Pfister [22] have introduced a stand-alone LCA-based procedure. Water Accounting and Vulnerability Evaluation (WAVE) model has been developed to enable the accounting of water use and the analysis of the vulnerability of a basin to potential impacts resulting from it [23]. Furthermore, the International Organization for Standardization has recently launched ISO 14046: 2014 project [24], aiming at creating an international standard for WF.

The accounting of green water is controversial, since in LCA based methods, it is considered that the consumption of green water itself does not contribute to water scarcity and due to the inseparability of green water and land, the consumption of green water in agricultural product life cycles is better considered in the context of the land use impact category [20]. As well, there is a conflict about estimating water consumption without taking into account the type of water used and the local scarcity of the studied area. For that reason, the Water Stress Index (WSI) was introduced as a coefficient of the water pressure that weighs WF. WSI for various basins worldwide were calculated by Pfister et al. [16]. According to Bradley Ridoutt and Stephan Pfister [20], it is misleading to sum different forms of water consumption with different opportunity costs as blue water has higher opportunity cost than green water [25], in areas that differ in their water shortages because impacts associated with all forms of consumption differ. They also mislead that the methodology by Arjen Hoekstra and Ashok Chapagain has developed independently from LCA and therefore, there is no clear relationship between WF and the potential caused social or environmental damage. On the other hand, Arjen Hoekstra et al. [26] maintain that volumetric WF contain highly relevant information, which disappears when translating volumes into arguable aggregated WF impact indices without physical interpretation, because it is completely meaningless in a water resources management context and that footprints were designed to show the pressure of humans on the environment, not the impacts.

\section{Results and Discussion}

\subsection{Regional and Basin Level}

As green water refers to agriculture sector which is also the main consumer of blue water, many WF studies deals with that sector. However, there is an effort to comprehend the majority of economic sectors of an examined area (Table 1). So far, owing to lack of data, studies which quantify grey WF are limited and mostly focused on nitrogen and phosphorus input from agriculture into water bodies [27-31]. In the case of bottom-up and top-down methods, both have been implicated in the river basin level. Bottom-up approach have been applied to Guadiana river basin, Heihe basin, Guadalquivir basin and 365 European basins [28, 32-34]. Multi-Regional Input-Output (MRIO) models have been used for the Yellow river basin and the Haihe basin $[10,35]$. Yet Yuan Zhi et al. [4] and $\mathrm{Xu}$ Zhao et al. [36] used a Generating Regional IO Tables (GRIT) method to bridge the gap in quantitative knowledge from the perspective of a river basin. Alberto Garrido et al. [37] applied a top down approach to evaluate the Spanish water footprint variations from year to year, not only at a national but also at provincial and river basin taking into consideration economic aspects. The WWF combined 
WF analysis and economic data for the horticulture and agriculture sectors in the lake Naivasha basin, in Kenya [38]. Some of the studies apart from surface water also estimate groundwater in WF accounting [4, 29, 32, 34, 39, 40]. Zhuo et al. [41] applied a sensitivity analysis method for the Yellow river basin to investigate the sensitivity of the WF of a crop to changes in input variables and parameters. Stuart Orr et al. [42] quantified additional land and water required to replace lost fish protein with livestock products, because of proposed dam construction in the lower Mekong basin.

\subsection{Administrative Unit}

Although WF accountings at river basin levels are more appropriate for decision making within water resources management than a traditional political unit [43], official data are not easily obtained at such a geographic region. In administrative scale, where trade data are more easily available, several papers are based on top-down approaches [44-47]. Huijuan Dong et al. [48] employed IO analysis method to evaluate not only the water footprint of the whole province but also water footprints of different economic sectors within this province. Yang $\mathrm{Yu}$ et al. [49] computed WFs of all sectors in the entire economy as well. Davy Vanham and Giovanni Bidoglio, Simona-Andreea Ene et al., Bulsink F. et al., Guoping Zhang et al., and San Luis Agua S. E. [50-54] included the grey water component.

Some studies divided countries in sub-catchments, mostly at provinces level to examine interactions within countries [37, 49, 52, 55]. Julian Fulton et al. [56] compared the U.S. WF to California's WF and found that policy-relevant differences stand out, arguing that such findings demonstrate that WF assessments may find more policy relevance when scaled to analytical units where water-related decision making occurs. Stanley Mubako et al. [57] investigated the geographical patterns of water footprint and virtual water trade among U.S. states and illustrated that the economic geography of the production of water-intensive products, and the institutions that link people to the sources of their WF is where the heart of the water scarcity issue lies.

Richard Rushforth and Benjamin Ruddell [58] were the first to comprehensively analyze water footprints and virtual water flows within a municipality in metropolitan area, intra-metropolitan area flows, and national scale flows simultaneously. They quantified water footprints and virtual water flows of the complete economy of the Phoenix metropolitan area's municipalities.

To link the spatially heterogeneous patterns of cities and ecosystem service production rates, Klaus Hubacek et al. [59] applied ascenario analysis based on input-output methodology and compared Beijing to China for the year 2020.

Daniele Bocchiola et al. [60] evaluated the impact of climate change upon WF and VW trade and benchmarked objectively adaptation strategies for agricultural systems. Guoping Zhang et al. [53] worked on a comprehensive project across 35 sub-catchments within the Hertfordshire and north London area that included blue, green and grey water footprints on surface and groundwater, for the domestic, industrial and agricultural sectors on a monthly basis and a climate change scenario for 2060 . Table 1 presents a synopsis of the studies.

\section{Conclusions}

Some analysts support that WF alone, contains too little pertinent information to guide policy makers who should also consider the social, political, and economic aspects of water use in any setting. Furthermore, they claim that water related problems should be solved locally and not through global governance schemes or trade barriers [61-63]. Besides, Arjen Hoekstra et al. [2] stress that it is still a partial tool. It provides information for water consumption and water scarcity but it does not account for water aspects like flooding. The grey WF methodology needs 
Table 1 Summary of studies that have evaluated the WF at the regional, basin and administrative unit level.

\begin{tabular}{|c|c|c|c|c|c|}
\hline $\begin{array}{l}\text { Geographical } \\
\text { unit* }\end{array}$ & Authors & Year & Area of study & $\begin{array}{l}\text { WF } \\
\text { components }\end{array}$ & Multisector \\
\hline $\mathrm{RB}$ & CTA et al. [27] & 2013 & Porce river basin (Colombia) & Blue, green, grey & $\checkmark$ \\
\hline $\mathrm{RB}$ & Dumont, A. et al. [34] & 2013 & Guadalquivir basin (Spain) & Blue, green & $\checkmark$ \\
\hline $\mathrm{RB}$ & Zeng, Z. et al. [33] & 2012 & Heihe river basin (China) & Blue, green & $\checkmark$ \\
\hline $\mathrm{R}$ & Aldaya, M. M. [29] & 2010 & Doñana region (Spain) & Blue, green, grey & $\checkmark$ \\
\hline $\mathrm{RB}$ & Aldaya, M., and Llamas, M. [32] & 2008 & Guadiana river basin (Spain) & Blue, green & $\checkmark$ \\
\hline $\mathrm{RB}$ & Vanham, D. and Bidoglio, G. [28] & 2014 & European river basins & Blue, green, grey & \\
\hline RB & De Miguel et al. [30] & 2015 & Duero river basin (Spain) & Blue, green, grey & \\
\hline $\mathrm{RB}$ & Marini, E. et al. [31] & 2015 & $\begin{array}{l}\text { Water district of western Peloponnese } \\
\text { (Greece) }\end{array}$ & Blue, green, grey & $\checkmark$ \\
\hline $\mathrm{RB}$ & Feng, K. et al. [35] & 2012 & Yellow river basin (China) & Blue, green & $\checkmark$ \\
\hline $\mathrm{RB}$ & White, D. J. et al. [10] & 2015 & Haihe river basin (China) & Blue & $\checkmark$ \\
\hline $\mathrm{RB}$ & Zhi, Y. et al. [4] & 2014 & Haihe river basin (China) & Blue & $\checkmark$ \\
\hline $\mathrm{RB}$ & Zhao, X. et al. [36] & 2010 & Haihe river basin (China) & Blue & $\checkmark$ \\
\hline LB & WWF [38] & 2010 & Lake Naivasha basin (Kenya) & Blue, green & $\checkmark$ \\
\hline $\mathrm{RB}$ & Hoekstra, A. Y. [39] & 2012 & 405 river basins & Blue & $\checkmark$ \\
\hline $\mathrm{RB}$ & Zhuo, L. et al. [41] & 2014 & Yellow river basin (China) & Blue, green & \\
\hline $\mathrm{RB}$ & Orr, S. et al. [42] & 2012 & Mekong river basin & & \\
\hline $\mathrm{R}$ & Aldaya, M. M. et al. [40] & 2009 & Mancha occidental region (Spain) & Blue, green & \\
\hline A & Zhang, Z. et al. [44] & 2011 & Beijing (China) & Blue & $\checkmark$ \\
\hline A & Zhang, C., and Anadon, L. D. [45] & 2014 & China provinces & Blue & $\checkmark$ \\
\hline A & Cazcarro, I. et al. [46] & 2010 & Huesca (Spain) & Blue & $\checkmark$ \\
\hline A & Wang, Z. et al. [47] & 2013 & Beijing (China) & Blue, grey & $\checkmark$ \\
\hline A & Dong, H. J. et al. [48] & 2013 & Liaoning (China) & Blue & $\checkmark$ \\
\hline A & Vanham, D., and Bidoglio, G. [50] & 2014 & Milan (Italy) & Blue, green, grey & $\checkmark$ \\
\hline A & Ene, S. A. et al. [51] & 2012 & Iasi county (Romania) & Blue, green, grey & $\checkmark$ \\
\hline A & Bulsink, F. et al. [52] & 2010 & Indonesian provinces & Blue, green, grey & \\
\hline A & Zhang, G. P. et al. [53] & 2014 & Hertfordshire and north London area & Blue, green, grey & $\checkmark$ \\
\hline $\mathrm{A} / \mathrm{RB}$ & Garrido, A. et al. [37] & 2010 & Spain provinces and river basins & Blue, green & $\checkmark$ \\
\hline A & Ma, J. et al. [55] & 2006 & North and south China & Blue, green & \\
\hline A & Yu, Y. et al. [49] & 2010 & Southeast and northeast UK & Blue, green & $\checkmark$ \\
\hline A & Fulton, J. et al. [56] & 2014 & California & Blue, green, grey & $\checkmark$ \\
\hline A & Mubako, S., and Lant, C. L. [57] & 2013 & Interstate transfers in the U.S. States & Blue, green & $\checkmark$ \\
\hline A & Rushforth, R., and Ruddel, B. [58] & 2015 & Phoenix, Arizona Metropolitan area & Blue & $\checkmark$ \\
\hline A & Hubacek, K. et al. [59] & 2009 & Beijing and China & Blue & $\checkmark$ \\
\hline A & Bocchiola, D. et al. [60] & 2013 & Po valley of Italy & Blue, green & \\
\hline A & $\begin{array}{l}\text { San Luis Agua S. E. Ministerio del } \\
\text { Campo and Gobierno de la } \\
\text { Provincia de San Luis [54] }\end{array}$ & 2015 & Province of San Luis & Blue, green, grey & $\checkmark$ \\
\hline
\end{tabular}

*A-Administrative unit, R-Region, RB-River Basin, LB-Lake Basin.

to be further standardized [64] and there is an absence of an agreed water quality standard to use when estimating dilution requirements [61]. More research needs to be done on sustainability assessment with an emphasison integration of social and economic factors. It is very important to take into account the environmental relevance and when accounting reduction targets regarding WFs within catchments, to 
be formulated on the basis of relative water scarcity per catchment [65]. The incorporation of climate change, uncertainties and economic consequences to WF studies needs to be strained. Moreover, databases on water availabilities and environmental flow requirements especially at the river basin level need to be improved, since the success on an application lays on the availability of data. There is a big challenge to establish a widely accepted concept for all WF components and environmental impacts in water accounting. However, there is a big progress in methodological evolution that allows more sophisticated and elaborated quantifications. WF provides helpful information for allocating water more efficiently, improving land-use planning, developing a water-saving culture and can contribute significantly to water resources and sustainability management in combination with other tools.

\section{References}

[1] Allan, J. A. 1993. Fortunately There are Substitutes for Water: Otherwise Our Hydropolitical Futures Would be Impossible. London: Overseas Development Administration.

[2] Hoekstra, A. Y., Chapagain, A. K., Aldaya, M. M., and Mekonnen, M. M. 2011. The Water Footprint Assessment Manual: Setting the Global Standard. London, UK: Earthscan.

[3] Hoekstra, A. Y. 2014. "Sustainable, Efficient and Equitable Water Use: The Three Pillars under Wise Freshwater Allocation." Wiley Interdisciplinary Reviews: Water 1 (1): 31-40.

[4] Zhi, Y., Yang, Z. F., and Yin, X. 2014. "Decomposition Analysis of Water Footprint Changes in a Water-Limited River Basin: A Case Study of the Haihe River Basin, China." Hydrology and Earth System Sciences 18 (5): 1549-1559. doi:10.5194/hess-18-1549-2014.

[5] Van, Oel, P. R., Mekonnen, M. M., and Hoekstra, A. Y. 2009. "The External Water Footprint of the Netherlands: Geographically-Explicit Quantification and Impact Assessment." Ecological Economics 69 (1): 82-92.

[6] Lenzen, M., and Foran, B. 2001. "An Input-Output Analysis of Australian Water Usage." Water Policy 3: 321-340.

[7] Leontief, W. 1936. "Quantitative Input-Ouput Relations in the Economic System of the United States." The Review of Economics and Statistics 18 (3): 105-125.
[8] Leontief, W. 1941. The Structure of American Economy: 1919-1929. Cambridge MA: Harvard University Press.

[9] Leontief, W. 1970. "Environmental Repercussions and the Economic Structure: An Input-Output Approach." Review of Economics and Statistics 52 (3): 262-271. doi:10.2307/1926294.

[10] White, D. J., Fenga, K., Suna, L., and Hubaceka, K. 2015. "A Hydro-Economic MRIO Analysis of the Haihe River Basin's Water Footprint and Water Stress." Ecological Modelling 318: 157-167.

[11] Gallego, B., and Lenzen, M. 2009. "Estimating Generalised Regional Input-Output Systems: A Case Study of Australia." In The Dynamics of Regions and Networks in Industrial Ecosystems. Cheltenham, UK: Edward Elgar Publishing.

[12] Yang, M., Pfister, S., and Bhaduri, A. 2013. "Accounting for a Scarce Resource: Virtual Water and Water Footprint in the Global Water System." Current Opinion in Environmental Sustainability 5 (6): 599-606.

[13] Feng, K., Hubacek, K., Minx, J., Siu, Y. L., Chapagain, A., and Yu, Y. et al. 2011. "Spatially Explicit Analysis of Water Footprints in the UK." Water 3: 47-63.

[14] Kitzes, J. 2013. "An Introduction to Environmentally-Extended Input-Output Analysis." Resources 2 (4): 489-503.

[15] Hawkins, J., Ma, C., Schilizzi, S., and Zhang, F. 2015. "Promises and Pitfalls in Environmentally Extended Input-Output Analysis for China: A Survey of the Literature." Energy Economics 48: 81-88.

[16] Pfister, S., Koehler, A., and Hellweg, S. 2009. “Assessing the Environmental Impacts of Freshwater Consumption in LCA.” Environmental Science \& Technology 43 (11): 4098-4104.

[17] Bayart, J. B., Bulle, C., Deschênes, C., Margni, M., Pfister S., and Vince, F. et al. 2010. "A Framework for Assessing Off-Stream Freshwater Use in LCA." The International Journal of Life Cycle Assessment 15 (5): 439-453.

[18] Boulay, A. M., Bouchard, C., Bulle, C., Deschênes, L., and Margni, M. 2011. "Categorizing Water for LCA Inventory." The International Journal of Life Cycle Assessment 16 (7): 639-651.

[19] Milà, Canals, L., Chenoweth, J., Chapagain, A., Orr, S., Antón, A., and Clift, R. 2008. "Assessing Freshwater Use Impacts in LCA: Part I-Inventory Modeling and Characterization Factors for the Main Impact Pathways." The International Journal of Life Cycle Assessment 14 (1): 28-42.

[20] Ridoutt, B. G., and Pfister, S. 2010. "A Revised Approach to Water Footprinting to Make Transparent the Impacts of Consumption and Production on Global Freshwater Scarcity." Global Environmental Change 20 
(1): 113-120.

[21] Rebitzer, G., Ekvallb, T., Frischknechtc, R., Hunkelerd, D., Norrise, G., and Rydbergf, T. et al. 2004. "Life Cycle Assessment Part 1: Framework, Goal and Scope Definition, Inventory Analysis, and Applications." Environment International 30 (5): 701-20.

[22] Ridoutt, B. G., and Pfister, S. 2012. "A New Water Footprint Calculation Method Integrating Consumptive and Degradative Water Use into a Single Stand-Alone Weighted Indicator." The International Journal of Life Cycle Assessment 18 (1): 204-207.

[23] Berger, M. 2014. "Water Footprint-Assessing Impacts of Water Use along Product Life Cycles." Accessed March 19, 2015. http://opus4.kobv.de/opus4-tuberlin/frontdoor/index/inde $\mathrm{x} /$ docId/5030.

[24] International Organization for Standardization. 2014. "ISO 14046: 2014, Environmental Management-Water Footprint-Principles, Requirements and Guidelines." Accessed June 20, 2015. http://www.iso.org/iso/catalogue_detail?csnumber=43263

[25] Chapagain, A. K., Hoekstra, A. Y., and Savenije, H. H. G. 2006. "Water Saving through International Trade of Agricultural Products." Hydrology and Earth System Sciences 10 (3): 455-468.

[26] Hoekstra, A. Y., Gerbens-Leenes, W., and Van Der Meer, T. H. 2009. "Reply to Pfister and Hellweg: Water Footprint Accounting, Impact Assessment, and Life-Cycle Assessment." The National Academy of Sciences 106 (40): E114-E114.

[27] Centre for Science and Technology of Antioquia (CTA), Swiss Agency for Development and Cooperation (COSUDE) and UNESCO Chair on Sustainability from the UPC. 2013. "Summary of Results, Water Footprint Assessment in River Basin Porce." Accessed September $10,2015$.

http://www.goodstuffinternational.com/images/PDF/Libr oHuellahidrica.pdf.

[28] Vanham, D., and Bidoglio, G. 2014. "The Water Footprint of Agricultural Products in European River Basins." Environmental Research Letters 9 (6): 064007.

[29] Aldaya, M. M., García-Novo, F., and Llamas, M. R. 2010. "Incorporating the Water Footprint and Environmental Water Requirements into Policy: Reflections from the Doñana Region (Spain).” Papeles De Agua Virtual, Botín Fundación. Accessed February 10, 2015. http://www.huellahidrica.org/Reports/Aldaya-et-al-2010Donana.pdf.

[30] De-Miguel, A., Kallache, M., and García-Calvo, E. 2015. "The Water Footprint of Agriculture in Duero River Basin.” Sustainability 7 (6): 6759-80.
[31] Marini, E., Papadopoulou, M. P., and Tsoukala, V. K. 2015. "Water Footprint Assessment in River Basin Scale Using GIS Technology." In Proceedings of 9th World Congress of EWRA, Water Resources Management in a Changing World: Challenges and Opportunities, 2-17.

[32] Aldaya, M., and Llamas, M. 2008. "Water Footprint Analysis for the Guadiana River Basin." Value of Water Research Report Series No. 35. Accessed July 20, 2015. http://scholar.google.com/scholar?hl=en\&btnG=Search\& $\mathrm{q}=$ intitle:Water+footprint + analysis + for + the + Guadiana + ri ver + basin + Value + of + Water + Research + Report + Series $+\mathrm{N}$ o. $+35 \# 0$.

[33] Zeng, Z., Liu, J., Koeneman, P. H., Zarate, E., and Hoekstra, A. Y. 2012. "Assessing Water Footprint at River Basin Level: A Case Study for the Heihe River Basin in Northwest China." Hydrology and Earth System Sciences 16 (8): 2771-2781.

[34] Dumont, A., Salmoral, G., and Llamas, M. R. 2013. “The Water Footprint of a River Basin with a Special Focus on Groundwater: The Case of Guadalquivir Basin (Spain)." Water Resources and Industry 1-2: 60-76.

[35] Feng, K., Siu, Y. L., Guanb, D., and Hubacek, K. 2012. "Assessing Regional Virtual Water Flows and Water Footprints in the Yellow River Basin, China: A Consumption Based Approach." Applied Geography 32 (2): 691-701.

[36] Zhao, X., Yang, H., Yang, Z., Chen, B., and Qin, Y. 2010. "Applying the Input-Output Method to Account for Water Footprint and Virtual Water Trade in the Haihe River Basin in China." Environmental Science \& Technology 44 (23): 9150-6.

[37] Garrido, A., Llamas, M. R., Varela-Ortega, C., Novo, P., Casado, R. R., and Aldaya, M. M. 2010. Water Footprint and Virtual Water Trade in Spain. New York: Springer.

[38] WWF. 2010. Shared Risk and Opportunity in Water Resources: Seeking a Sustainable Future for Lake Naivasha. Godalming, UK: WWF and PEGASYS.

[39] Hoekstra, A. Y., Mekonnen, M. M., Chapagain, A. K., Mathews, R. E., and Richter, B. D. 2012. "Global Monthly Water Scarcity: Blue Water Footprints versus Blue Water Availability." PLoS ONE 7 (2): e32688.

[40] Aldaya, M. M., Martinez-Santos, P., and Llamas, M. R. 2009. "Incorporating the Water Footprint and Virtual Water into Policy: Reflections from the Mancha Occidental Region, Spain." Water Resources Management 24 (5): 941-958.

[41] Zhuo, L., Mekonnen, M. M., and Hoekstra, A. Y. 2014. "Sensitivity and Uncertainty in Crop Water Footprint Accounting: A Case Study for the Yellow River Basin." Hydrology and Earth System Sciences 18 (6): 2219-2234.

[42] Orr, S., Pittock, J., Chapagain, A., and Dumaresqd, D. 2012. "Dams on the Mekong River: Lost Fish Protein and 
the Implications for Land and Water Resources." Global Environmental Change 22 (4): 925-932.

[43] EC. 2012. River Basin Management Plans. Report on the Implementation of the Water Framework Directive (2000/60/EC).

[44] Zhang, Z., Yang, H., and Shi, M. 2011. "Analyses of Water Footprint of Beijing in an Interregional Input-Output Framework." Ecological Economics 70 (12): 2494-2502.

[45] Zhang, C., and Anadon, L. D. 2014. "A Multi-Regional Input-Output Analysis of Domestic Virtual Water Trade and Provincial Water Footprint in China." Ecological Economics 100: 159-172.

[46] Cazcarro, I., Pac, R. D., and Sánchez-Chóliz, J. 2010. "Water Consumption Based on a Disaggregated Social Accounting Matrix of Huesca (Spain)." Journal of Industrial Ecology 14 (3): 496-511.

[47] Wang, Z., Huanga, K., Yang, S., and Yuc, Y. 2013. “An Input-Output Approach to Evaluate the Water Footprint and Virtual Water Trade of Beijing, China." Journal of Cleaner Production 42: 172-179.

[48] Dong, H. J., Geng, Y., Sarkis, J., Fujita, T., Okadera, T., and Xue, B. 2013. "Regional Water Footprint Evaluation in China: A Case of Liaoning." The Science of the Total Environment 442: 215-224.

[49] Yu, Y., Hubacek, K., Feng, K., and Guan, D. 2010. "Assessing Regional and Global Water Footprints for the UK." Ecological Economics 69 (5): 1140-47.

[50] Vanham, D., and Bidoglio, G. 2014. "The Water Footprint of Milan." Water Science and Technology: A Journal of the International Association on Water Pollution Research 69 (4): 789-95.

[51] Ene, S. A., Hoekstra, A. Y., Mekonnen, N. N., and Teodosiu, C. 2012. "Water Footprint Assessment in North-Eastern Region of Romania: A Case Study for the Iasi County, Romania." Journal of Environmental Protection and Ecology 516 (2): 506-516.

[52] Bulsink, F., Hoekstra, A. Y., and Booij, M. J. 2010. "The Water Footprint of Indonesian Provinces Related to the Consumption of Crop Products." Hydrology and Earth $\begin{array}{llll}\text { System } & \text { Sciences } & 14 & \text { (1): }\end{array}$ doi:10.5194/hess-14-119-2010.

[53] Zhang, G. P., Mathews, R. E., Frapporti, G., and Mekonnen, M. M. 2014. "Water Footprint Assessment for the Hertfordshire and North London Area." Water Footprint Network. Accessed September 10, 2015. http://www.waterfootprint.org/Reports/wfa_hfs_nla.pdf.

[54] San Luis Agua and Gobierno De La Provincia De San
Luis. 2015. "Reckoning and Analysis of the Water Footprint of the Province of San Luis: Agricultural and Livestock Sectors." Accessed September 10, 2015. http://waterfootprint.org/media/downloads/WF_San_Luis _Version_Final.pdf.

[55] Ma, J., Hoekstra, A. Y., Wang, H., Chapagain, A. K., and Wang, D. 2006. "Virtual Versus Real Water Transfers within China." Philosophical Transactions of the Royal Society of London, Series B, Biological Sciences 361 (1469): 835-842.

[56] Fulton, J., Cooley, H., and Gleick, P. H. 2014. "Water Footprint Outcomes and Policy Relevance Change with Scale Considered: Evidence from California." Water Resources Management 28: 3637-3649.

[57] Mubako, Stanley, T., and Christopher, Lant, L. 2013. "Agricultural Virtual Water Trade and Water Footprint of U.S. States." Annals of the Association of American Geographers 103 (2): 385-396.

[58] Rushforth, R. R., and Ruddell, L. B. 2015. "The Hydro-Economic Interdependency of Cities: Virtual Water Connections of the Phoenix, Arizona Metropolitan Area." Sustainability 7 (7): 8522-47.

[59] Hubacek, K., Guan, D., Barrett, J., and Wiedmann, T. 2009. "Environmental Implications of Urbanization and Lifestyle Change in China: Ecological and Water Footprints." Journal of Cleaner Production 17: 1241-1248.

[60] Bocchiola, D., Nana, E., and Soncini, A. 2013. "Impact of Climate Change Scenarios on Crop Yield and Water Footprint of Maize in the Po Valley of Italy." Agricultural Water Management 116: 50-61.

[61] Perry, C. 2014. "Water Footprints: Path to Enlightenment, or False Trail?" Agricultural Water Management 134: 119-125.

[62] Wichelns, D. 2010. "Virtual Water and Water Footprints: Policy Relevant or Simply Descriptive?" International Journal of Water Resources Development 26 (4): 689-695.

[63] Gawel, E., and Bernsen, K. 2011. "Do We Really Need a Water Footprint? Global Trade, Water Scarcity and the Limited Role of Virtual Water." GAIA 21 (3): 162-167.

[64] Thaler, S., Zessner, M., Bertran De Lis, F., Kreuzinger, N., and Fehringer, R., 2012. "Considerations on Methodological Challenges for Water Footprint Calculations.” Water Science and Technology 65: 1258-1264.

[65] Hoekstra, A., and Mekonnen, M. 2012. "Reply to Ridoutt and Huang: From Water Footprint Assessment to Policy." The National Academy of Sciences 109: E1425-E1425. 